\title{
Atletski trener sa autoritetom znanja
}

Goran Obradović

Trener Ivane Španović

\section{Planovi}
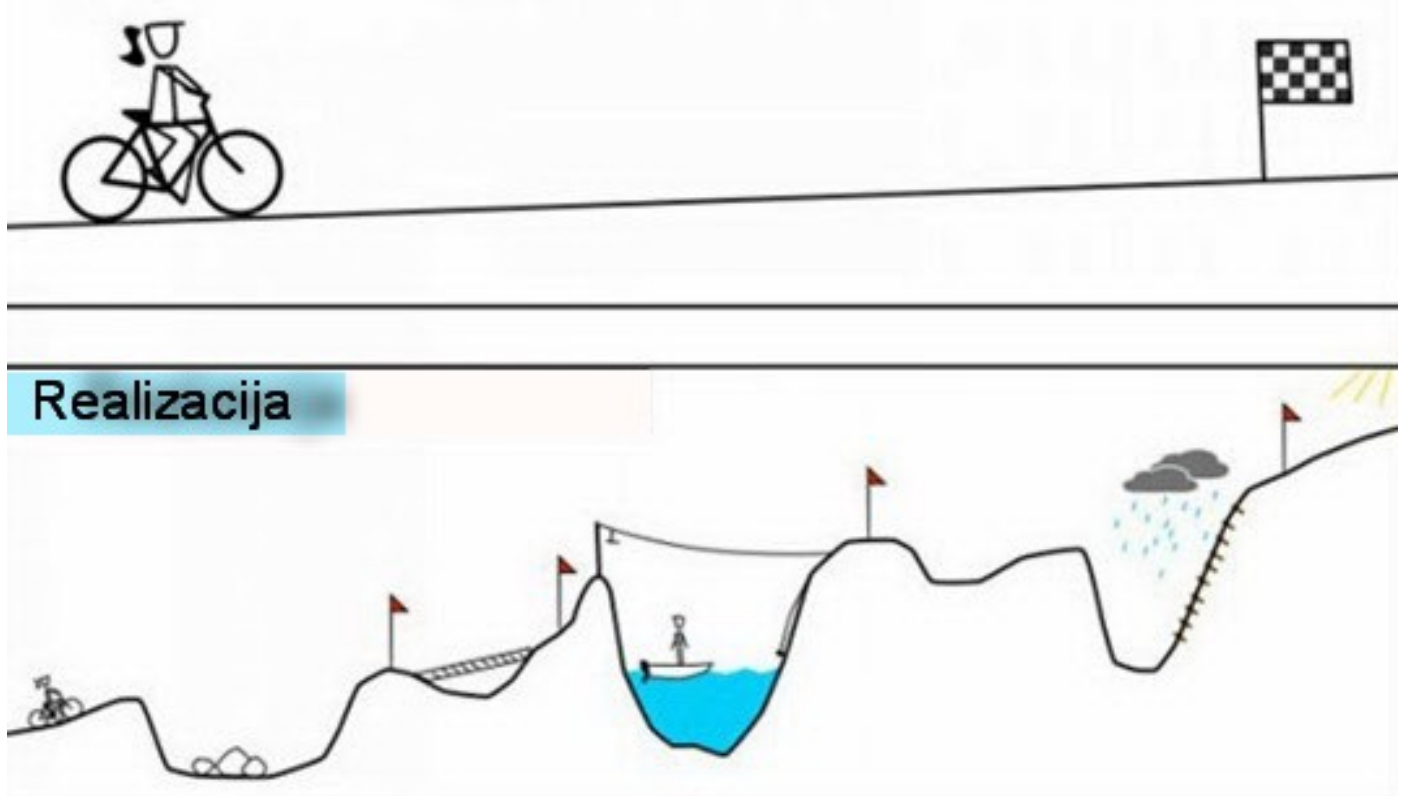

Slika 1 


\section{Vaši osnovni podaci?}

Rođen sam u Novom Sadu 1971.

Srednju elektrotehničku školu sam završio 1989. i iste sam upisao Fakultet fizičke kulture u Novom Sadu.

Nakon odsluženja vojnog roka 1990. godine počinjem sa studijama.

Trenersku karijereu započinjem 1995. sa grupom skakača koju je trenirao Ferenc Kamasi (Zorić, Niketić, Milinkov, Socek, Kamasi, itd).

Diplomu višeg sportskog trenera na usmerenju za atletiku i fizičku pripremu dobijam 2005. na Sportskoj akademiji u Beogradu.

\section{Sportovi kojima ste se aktivno bavili?}

Atletikom sam počeo da se bavim 1982. disciplinom skok uvis kod trenera Ferenca Kamasija.

Najznačajnije rezultate, kao atletičar, postigao sam 1991. i 1992. osvajanjem srebrnih medalja na državnim prvenstvima.

\section{Kažite nam nešto o vašoj filozofiji treninga?}

Periodizacija je osnova svih trenažno takmičarskih postavki.

Bez nje je nemoguće upravljati razvojem motoričkih sposobnosti i tempiranjem forme (Grafikon 1)

Improvizacija u okviru periodizacije je ključna u momentima, kada se periodizacija iz objektivnih razloga, mora promeniti (bolesti, povrede, itd).

$\mathrm{Na}$ grafikonu 2. se vidi grafikon trenažnog opterećenja u okviru jednog mezociklusa.

$\mathrm{Na}$ grafikonu 3. se vidi improvizacija u okviru mezociklusa sa slike levo.

U trećej nedelji mezociklusa sportista se razboleo i 7 dana nije trenirao. $U$ četvrtoj nedelji ga vraćamo na opterećenje iz druge nedelje i tek onda nastavljamo sa daljim razvojem.

Zaključak: Sportista koji je bio odsutan sa treninga 7 dana, nije izgubio 7 dana od trenažnog procesa, već četrnaest, jer je potrebno vreme da bi rekovalescenta vratili na poziciju pre bolesti (Slika 1).

Znanje je danas dostupno svima, ali primena istih na individuu je umetnost.

Vrhunski sportisti se rađaju. $\mathrm{Na}$ nama trenerima je da iz njih izvučemo maksimum.

Nije bitno koliko se trenira, već kako se trenira.

Ne koljite bika za jednu šniclu.

\section{Grafikon 1 Zimski mikrociklus}

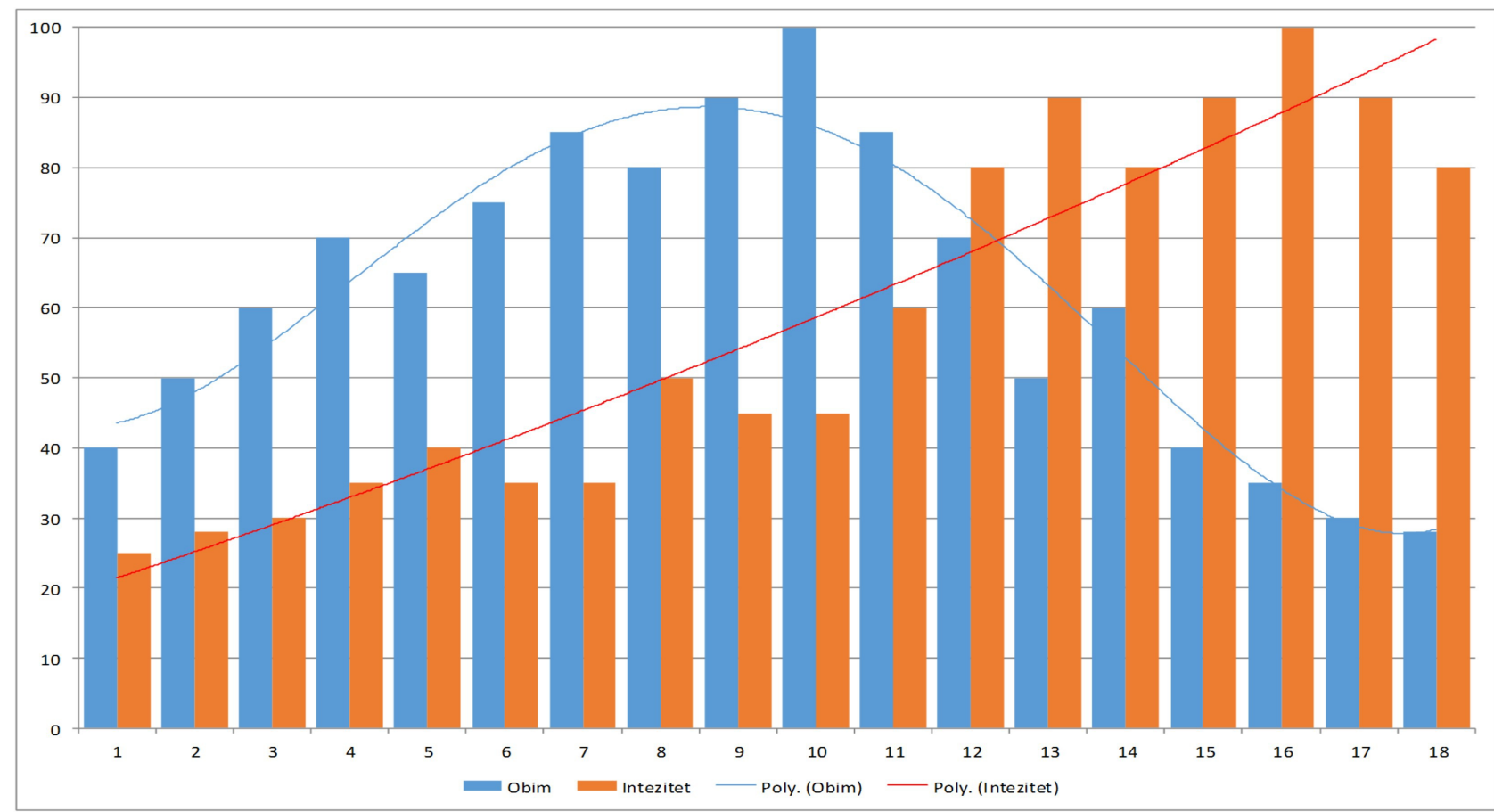


Grafikon 2 Jedan mezociklus

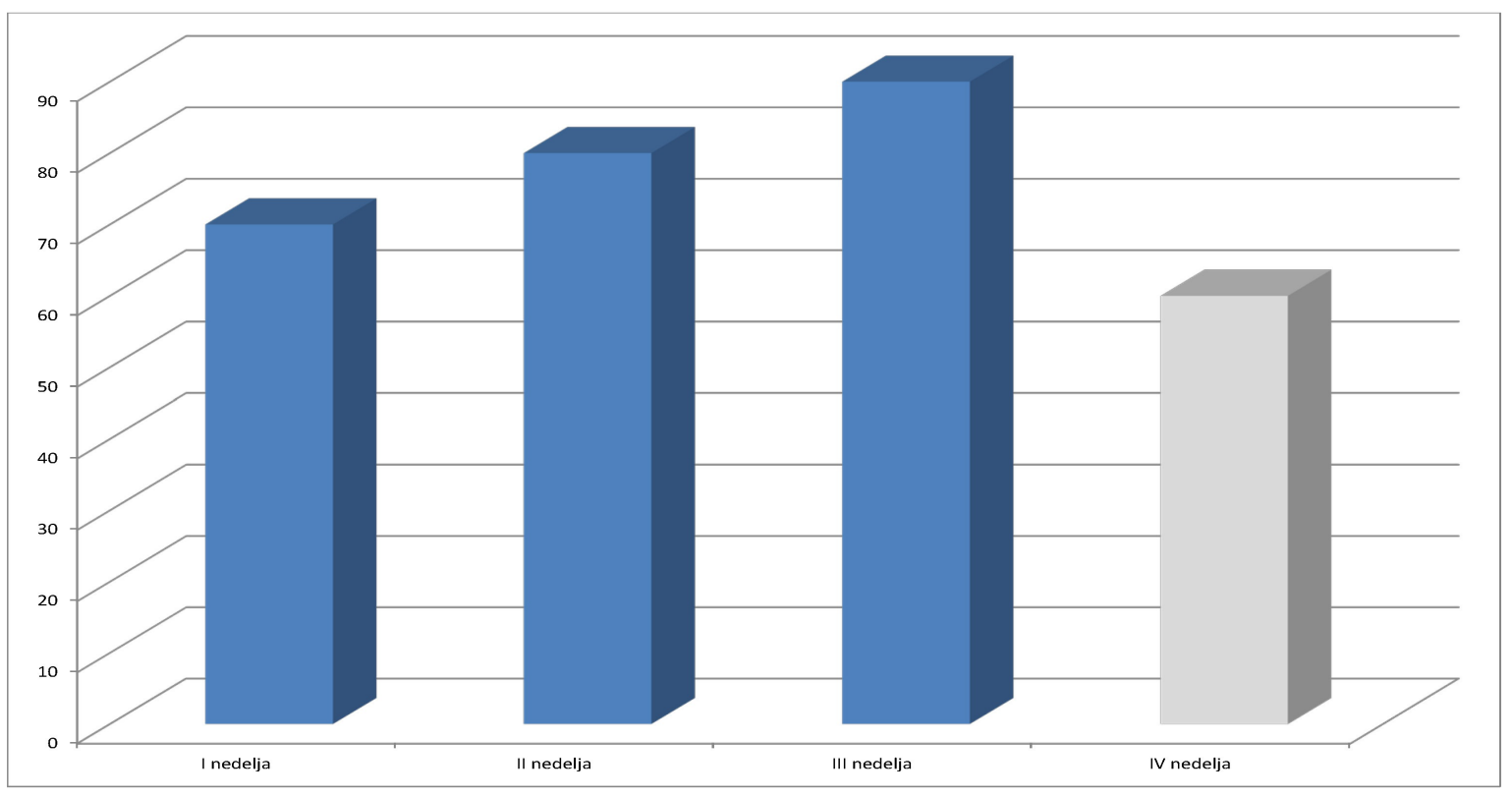

Grafikon 3

\section{IMPROVIZACIJA}

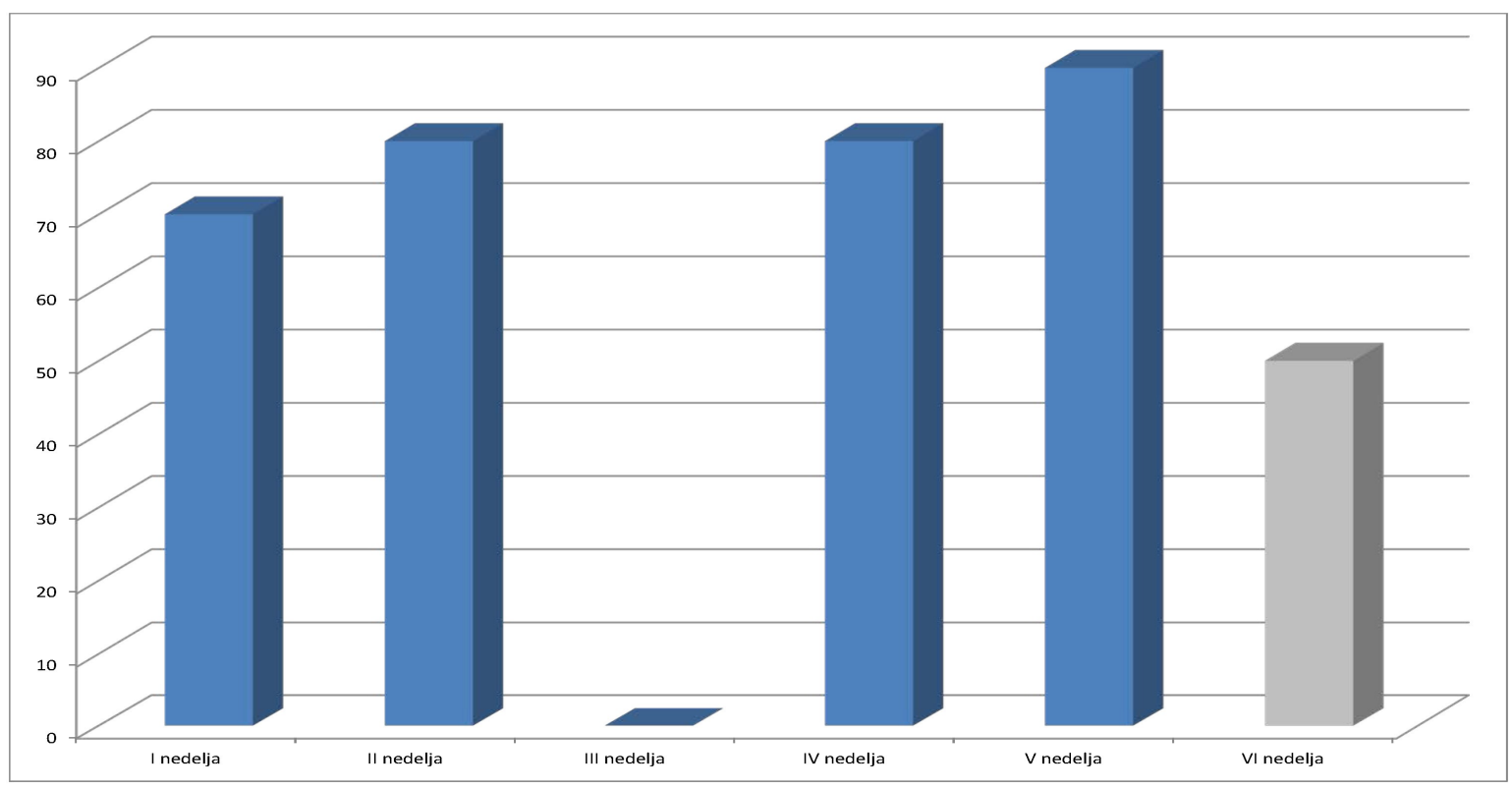




\section{Koje su motoričke sposobnosti ključne za vrhunski rezultat $u$ disciplini skok u dalj?}

Kada govorimo o bazičnim motoričkim sposobnostima, onda su to: snaga, brzina i koordinacija.

Kada govorimo o specifičnim motoričkim sposobnostima, onda je to eksplozivna snaga.

Zaletna brzina i odraz su direktno vezani za eksplozivnu snagu. Razvoj na istoj je ključan za postizanje vrhunskog rezultata u skoku udalj.

\section{Koje su to kritične hronološke tačke u razvoju vrhunskog skakača u dalj?}

Prvo i osnovno je selekcija. U mlađim uzrasnim kategorijama, moramo prepoznati decu koja po svojim fizičkim karakteristikama, odgovaraju profilu sprinter-skakač.

Zatim kroz višebojski trening možemo profilisati potencijalnu disciplinu kojom će se baviti sportista.

Zatim sledi specijalizacija i postavka višegodišnjih planova razvoja buduće discipline.

Sa ulaskom u seniorski staž sledi potpuna individualizacija treninga.

I sportista $i$ trener se $u$ novonastalim situacijama uče i koriguju trening i tehniku $u$ odnosu na prethodnu sezonu. Korekcije ne smeju biti radikalne, već usmerene ka postizanju realnih ciljeva koji su u svakom slučaju veći, nego što su bili u prethodnoj sezoni.

\section{Koliko bi optimalno testova i mernih tačaka trebalo koristiti u sezoni? Kontrola tokom različitih ciklusa priprema?}

Ja koristim kontrolu treniranosti nakon svakog mezociklusa.

Pošto svaki ciklus ima specifiku koji ga obeležava, testovi su zbog toga tipični za dati ciklus.

U takmičarskom periodu takmičenja su testovi sami za sebe, sem u pripremnom ciklusu za glavni cilj takmičarske sezone (svetska i evropska prvenstva), kada se koriste testovi eksplozivne snage, koji su tipični pokazatelji forme u kojoj se sportista nalazi.

\section{Ishrana i farmakologija u vrhunskom sportu?}

Ishrana je jedan od važnih faktora $u$ vrhunskom sportu, a naročito u skakačkim disciplinama.

Odstupanje od idealne telesne mase znači i slabiji sportski rezultat.

Ishrana mora biti izbalansirana i primerena trenažnom ciklusu. Naročito se to odnosi na suplementaciju.

Mnogo se polemiše oko suplementacije vrhunskih sportista i unosi dosta zabuna.

95\% uspeha su trenažni uslovi i dobro planiran i usmeren trening. $U$ preostalih $5 \%$ ubraja se farmakologija. Ovo govorim zbog toga što mnogi treneri, pa i sportisti, smatraju da uz pomoć dodatne suplementacije mogu popraviti sportski rezultat mnogo više od realnog.

\section{Osvrt na Vaš rad sa Ivanom Španović}

Sa Ivanom sam počeo saradnju 2010. Nakon završetka srednje škole odlučila je da dođe u Novi Sad, gde su uslovi za trening bili daleko bolji od uslova koje joj je Zrenjanin pružao. Naše „upoznavanje“ je trajalo nešto duže, nego što je obično. Nismo govorili istim ,jezikom“, pa nam je trebalo više vremena za sporazumevanje. Od Ivane se očekivalo da nastavi niz juniorskih uspeha i u seniorskoj kategoriji. Bio je to veliki pritisak za nju, a i za mene. Ključni trenutak je bio 2012, kada je Novi Sad dobio uslove za trening i takmičenja $u$ zatvorenom prostoru - Hala I Novosadskog sajma. Prvi put smo mogli u kontinuitetu da radimo na razvoju brzine i na unapređenju tehnike.

Od 2013. pa do danas, Ivana je osvojila 5 medalja (3 svetske i 2 evropske), oborila nacionalne rekorde u skoku udalj, 60m i petoboju. Sa ovim rezultatima Ivana je postala najuspešniji atletičar u istoriji Srbije.

\section{Koja ste sredstva i metode koristili u svom radu u cilju bržeg oporavka?}

$\mathrm{U}$ današnjem sportskom treningu oporavak ima isti značaj, kao i trening. Bez dobrog oporavka nema ni dobrog treninga. Znamo da se superkompenzacija događa nakon obaranja trenažnog opterećenja, a za to je najzaslužniji dobar oporavak i odmor. 
Kao broj jedan za oporavak je najzaslužniji odmor. Dan ili dani kada sportista nema fizičke aktivnosti.

Kao broj dva fizioterapija - masaža

Kao broj tri smatram regenerativni trening.

Kao broj četiri krio terapija - ledene kade.

Kao broj pet suplimentacija - farmakologija vitaminizacija.

\section{Očekivanja za narednu Olimpijsku sezonu.}

Da bismo planirali budućnost, moramo se vratiti nekoliko godina $u$ nazad i pozabaviti se statistikom.

Ako pogledamo Ivanin razvojni put, možemo zaključiti da sa optimizmom možemo očekivati narednu sezonu (Grafikon 4).

Međutim, osvrnuo bi se na takmičarsku sezonu 2011-2012. Sezonu, kada je Ivana imala stagnaciju i regresiju u rezultatu. Ta regresija je bila direktno vezana za tešku povredu (stres fraktura navikularne kosti), koju je Ivana doživela u drugoj polovini 2011. godine.

Ovo napominjem da bih ukazao da je zdravlje sportista najvažnije i da ćemo sve učiniti kako bismo ga sačuvali. To podrazumeva idealan balans između treninga i odmora, kao i izbegavanje visokorizičnih trenažnih sredstava.
Ivana je od 2013. godine permanentno obarala lične rekorde, ali je i značajno podigla nivo skokova (Tabela 1).

Da bi Ivana dostigla potrebni nivo skokova na određenim daljinama potrebna su joj i kvalitetna takmičenja. Ivana se od 2013. godine takmiči u svetskom atletskom „cirkusu“ - Dijamatskoj ligi.

Organizatori mitinga i menadžeri od sportista očekuju visok nivo rezultata tokom cele takmičarske sezone (odnosi se samo na letnju takmičarsku sezonu).

Periodizaciju koju predstavljam korišćena je u takmičarskoj sezoni 2014. godine i pokazala se kao izvanredna (Grafikoni 5 i 6 ).

I za takmičarsku sezonu 2015. koristio sam istu periodizaciju, ali ona je morala doživeti improvizaciju (korekciju), zbog Ivanine povrede nakon prvog takmičenja u sezoni - Doha DL (Grafikon 7).

Nekada je bilo nezamislivo da se u okviru jedne takmičarske sezone postavljaju više od dva pika.

Današnja periodizacija nam dozvoljava i do četiri pika u jednoj sezoni, sa tim da se ostavlja dovoljno prostora za završne pripreme za glavni cilj takmičarske sezone.

Grafikon 4

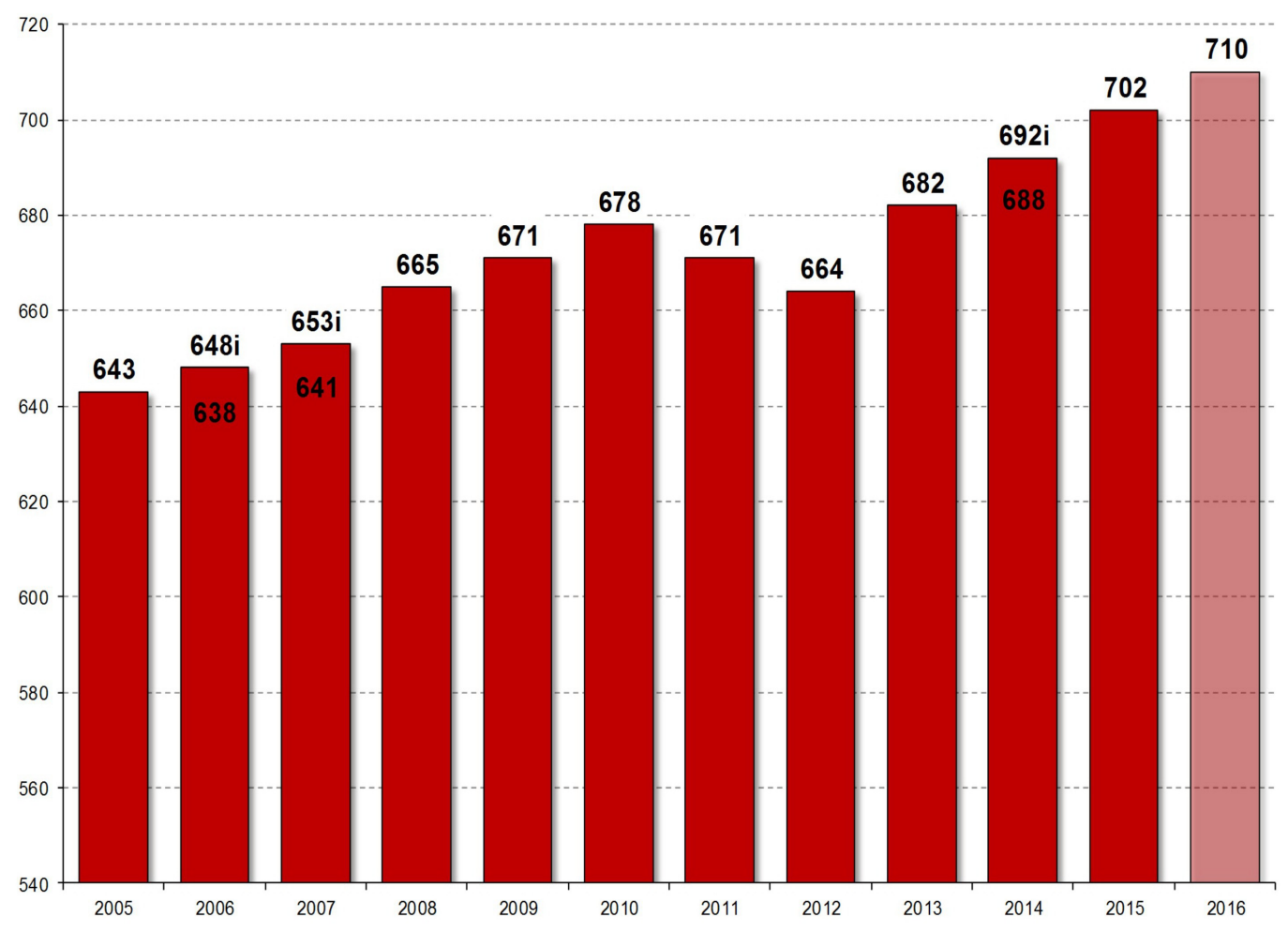


Tabela 1

\begin{tabular}{|c|c|c|c|c|c|}
\hline Godina & $\begin{array}{c}\text { Broj } \\
\text { Takmičenja }\end{array}$ & 670 & 680 & 690 & 700 \\
\hline 2013. & 16 & 7 & 1 & 0 & 0 \\
\hline 2014. & 17 & 21 & 7 & 1 & 0 \\
\hline 2015. & 13 & 25 & 16 & 8 & 3 \\
\hline
\end{tabular}

Grafikon 5

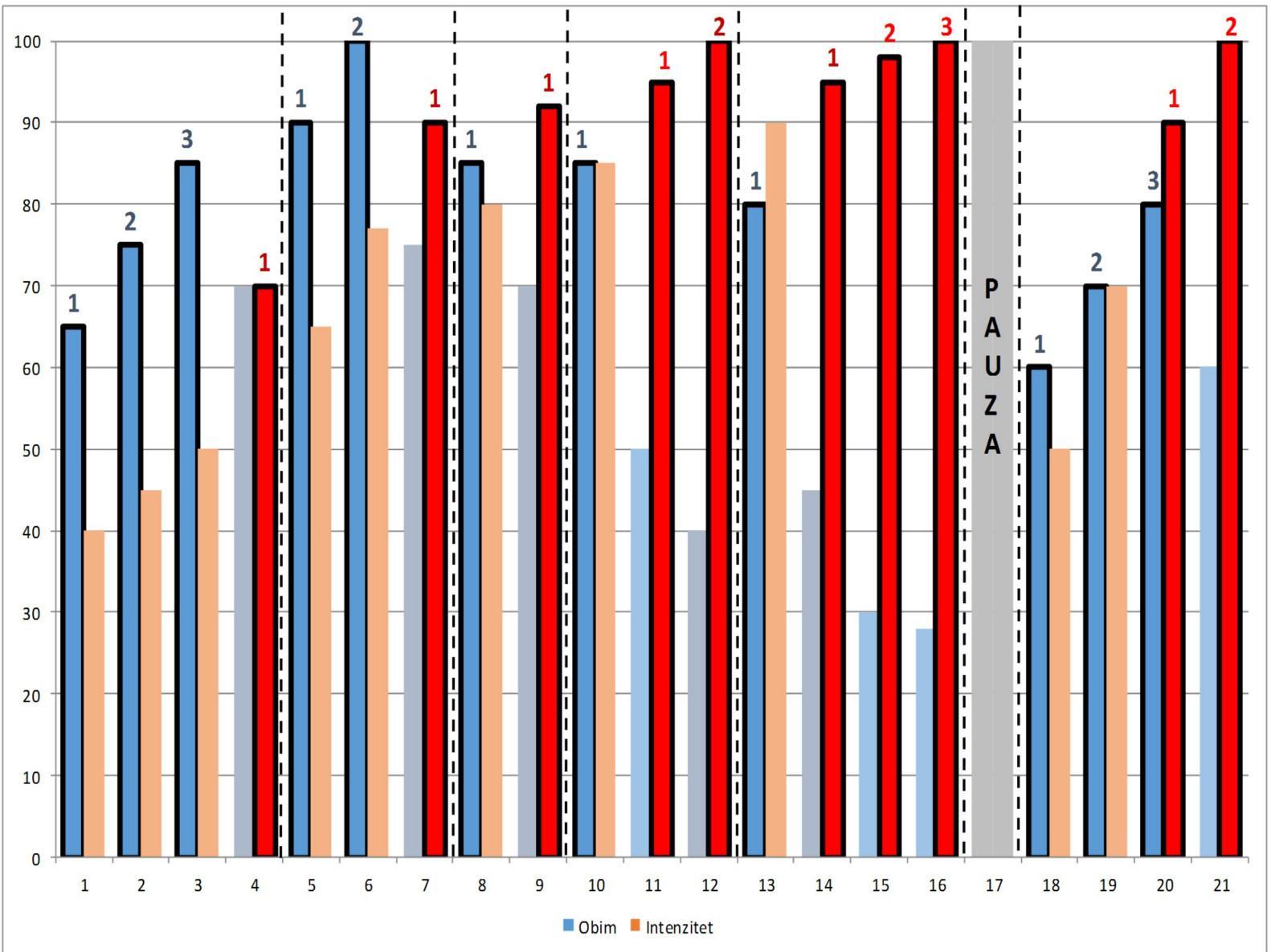


Grafikon 6

TAKMIČARSKA SEZONA 2014

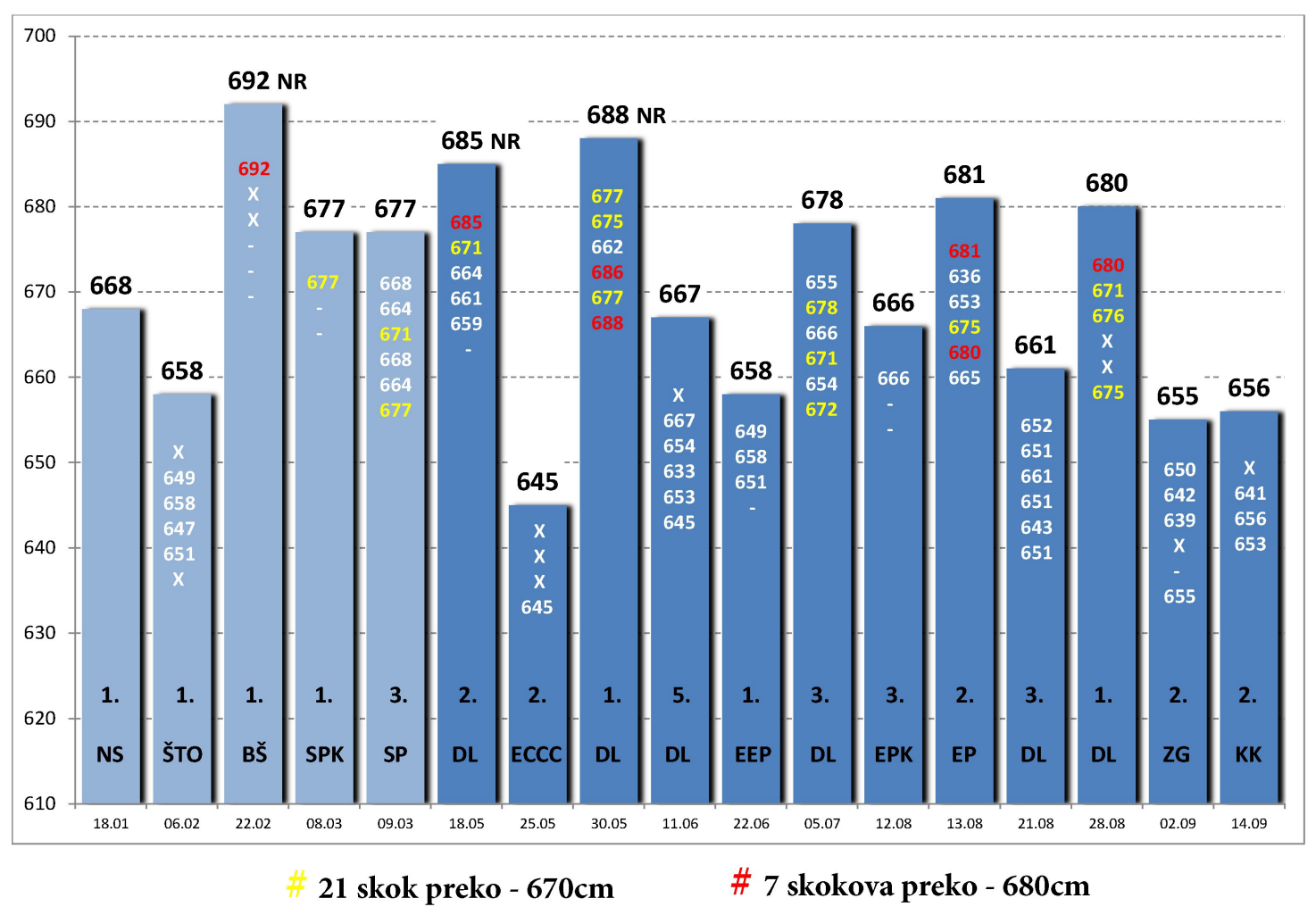

Grafikon 7 Takmičarska sezona 2015.

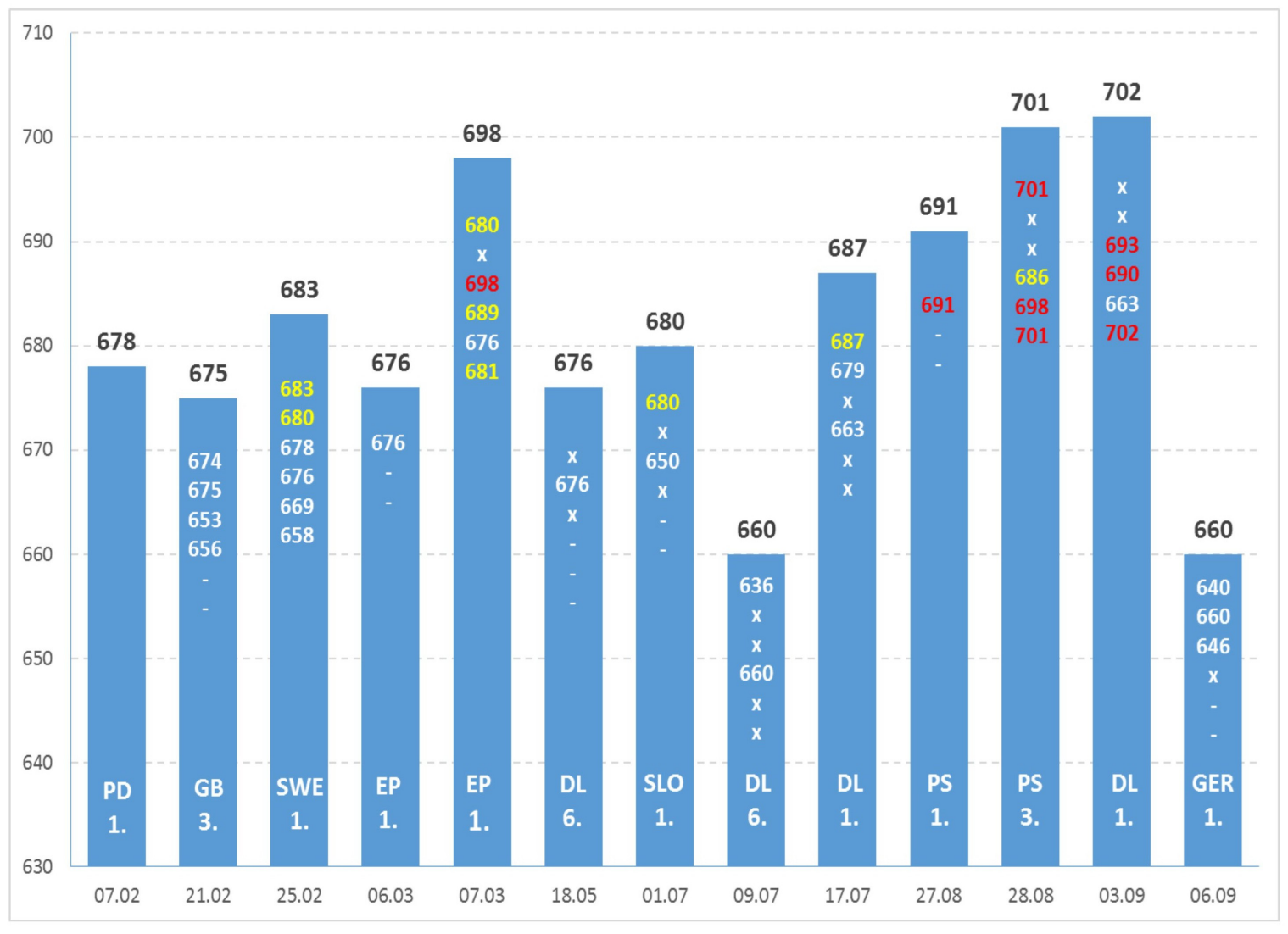

